\title{
Effects of salinity and nutrients on sedimentary bacterial communities in oligosaline Lake Bosten, northwestern China
}

\author{
Jiangyu Dai ${ }^{1,2}$, Xiangming Tang ${ }^{1}$, Guang Gao ${ }^{1, *}$, Dan Chen $^{1,2}$, Keqiang Shao ${ }^{1}$, \\ Xianlei Cai ${ }^{1,2}$, Lei Zhang ${ }^{1,2}$
}

\author{
${ }^{1}$ State Key Laboratory of Lake Science and Environment, Nanjing Institute of Geography and Limnology, \\ Chinese Academy of Sciences, Nanjing 210008, PR China \\ ${ }^{2}$ Graduate School of Chinese Academy of Sciences, Beijing 100049, PR China
}

\begin{abstract}
Lake Bosten, a large oligosaline lake in arid northwestern China, has evolved from a freshwater lake and is influenced by eutrophication processes. Since sediments record past limnic changes, the analysis of sedimentary bacteria in Lake Bosten may help elucidate bacterial responses to both salinization and eutrophication. We characterized the intrasystem distribution of sedimentary bacterial communities between freshwater and oligosaline regions of Lake Bosten using denaturing gradient gel electrophoresis and 16S rRNA gene clone libraries. Both principal component analysis and redundancy analysis revealed that salinity was the dominant and pronounced intrasystem factor that shaped the sedimentary bacterial community composition in Lake Bosten. In total, 349 clones and 185 distinct operational taxonomic units were acquired from 4 clone libraries. Proteobacteria ( $41.5 \%$ ) was the most abundant phylum, followed by Bacteroidetes $(13.5 \%)$, Chloroflexi $(8.9 \%)$, Firmicutes $(8.6 \%)$ and others. The higher bacterial diversities and proportions of Beta- and Deltaproteobacteria in the oligosaline regions than in the freshwater region reflected the responses of sedimentary bacteria to increased salinity and nutrient levels. The scarceness of typical freshwater bacteria, the relatively high percentage $(12.3 \%$ of total bacteria) of putative sulfate-reducing bacteria and a high percentage of unclassified bacteria in the sediments all highlight the uniqueness of sedimentary bacterial communities in the early stages of salinization and eutrophication.
\end{abstract}

KEY WORDS: Lake Bosten $\cdot$ Sediment $\cdot$ Salinity $\cdot$ Nutrient $\cdot$ Bacterial community composition

\section{INTRODUCTION}

In inland areas, limnic ecosystems are frequently used as models for studying the response of aquatic bacterial communities to dominant environmental factors, such as salinity (Wu et al. 2006, Jiang et al. 2007, Wang et al. 2011, Tang et al. 2012), nitrogen and phosphorus levels (Tang et al. 2010) and organic matter (Fujii et al. 2012). Most of the lakes that have previously been studied are either freshwater or saline, and only a few studies have focused on oligo- saline lakes (Wu et al. 2006, Liu et al. 2010, Tang et al. 2012). In arid regions of Central Asia, many freshwater lakes have evolved to be oligosaline in the past $30 \mathrm{yr}$ due to climatic change and uncontrolled resource exploitation (Bai et al. 2011). However, the impact of these environmental changes on bacterial communities may be accurately recorded in limnic sediments (Chen et al. 1999). Sedimentary bacteria, as a result of their high cell abundance $\left(>10^{8}\right.$ cells $\mathrm{g}^{-1}$ ) (Schmidt et al. 1998, Danovaro et al. 2002), play a crucial role in ecological and biogeochemical pro- 
cesses (Nealson 1997). The characteristics of sedimentary bacteria, including their biomass and community structure, are determined by the variability in physicochemical and biotic parameters, and can thus be regarded as representative indicators of environmental change (Zhang et al. 2008). Although salinity is regarded as one of the most important global determinants of bacterial communities (Lozupone \& Knight 2007), it is not well known whether increases in salinity shape sedimentary bacterial communities in oligosaline lakes.

Lake Bosten, the largest oligosaline lake in the arid region of China, is representative of an oligosaline lake that evolved from a freshwater lake (Bai et al. 2011). The freshwater inflows supplied by melting ice, precipitation and groundwater in the mountainous regions of Tianshan (Xiao et al. 2010) helped shape the freshwater region of this lake and shift the salinity gradient from freshwater to oligosaline in this lake (Tang et al. 2012). Meanwhile, a trophic gradient from oligotrophic to mesotrophic also formed due to anthropogenic agricultural and tourism activities (Xie et al. 2011). Such a complex ecosystem is an ideal model to study the responses of bacterial communities to gradients in salinity and nutrients (Tang et al. 2012). However, little is known about the responses of sedimentary bacterial community composition (BCC) to increased salinity and nutrient levels in oligosaline lakes or which bacterial phylotypes are particularly sensitive to such changes.

To address the aforementioned issues, in the present study, we (1) investigated whether salinity and/or nutrient levels were the main environmental parameters shaping the sedimentary BCC, by analyzing the spatial distribution of sedimentary BCC in response to salinity and nutrient gradients in Lake Bosten, and (2) identified the dominant bacterial phylotypes that are sensitive to alterations in salinity and nutrient levels in sediments. Our results provide a framework for understanding the sedimentary $\mathrm{BCC}$ in oligosaline environments in the arid region of China and shed light on responses of sedimentary $\mathrm{BCC}$ to the processes of salinization and eutrophication.

\section{MATERIALS AND METHODS}

\section{Sampling sites}

Lake Bosten $\left(86^{\circ} 40^{\prime}-87^{\circ} 26^{\prime} \mathrm{E}, 41^{\circ} 56^{\prime}-42^{\circ} 14^{\prime} \mathrm{N}\right)$ spans $55 \mathrm{~km}$ from east to west and $25 \mathrm{~km}$ from north to south, covering an area of $\sim 1100 \mathrm{~km}^{2}$ (Mischke \& Wünnemann 2006). Over the course of a year, the average water depth is $7 \mathrm{~m}$, with a maximum depth of $16 \mathrm{~m}$ (Sai et al. 2011). Water stratification in the lake depends mainly on the inflow of meltwater from the Kaidu River and the outflow through the Kongqi River which ends in the Tarim Basin (Mischke \& Wünnemann 2006). Sixteen sites across the lake were chosen for collecting sediment samples on 23 and 24 August 2010 (Fig. 1). Of these sampling sites, Sites $\mathrm{L}$ and $\mathrm{M}$ were located near the Kaidu River, which is an isolated freshwater region. All the other sites were located in oligosaline regions, which are influenced by human activities in agriculture or tourism. For example, Sites D and E were near the tourist area of the Jinsha Shore along the eastern lakeshore. Sites G and $\mathrm{H}$ were influenced by saline and eutrophic irrigation drainage from the northern lakeshore.

\section{Sample collection and physicochemical analysis}

The temperature, $\mathrm{pH}$, dissolved oxygen (DO), salinity and total dissolved solids (TDS) of the lowest layer of water overlying the sediments were measured in situ using a YSI 6600 Multi-Parameter Water Quality Sonde. Surface sediment (0 to $5 \mathrm{~cm}$ ) samples from all sites were collected using a $1 / 16 \mathrm{~m}^{2}$ Petersen grab sampler and stored in a refrigerated container with ice bags until analysis. All analyses were conducted within $24 \mathrm{~h}$ of sampling. Aliquots of sediment samples were stored at $-80^{\circ} \mathrm{C}$ for bacterial cell counting and DNA extraction. Interstitial water from the sediment samples was collected by centrifuging samples at $1000 \times g$ for $5 \mathrm{~min}$ and then used to determine the concentrations of chloride $\left(\mathrm{Cl}^{-}\right)$and sulfate $\left(\mathrm{SO}_{4}{ }^{2-}\right)$ with an ICS 2000 Ion Chromatography sys-

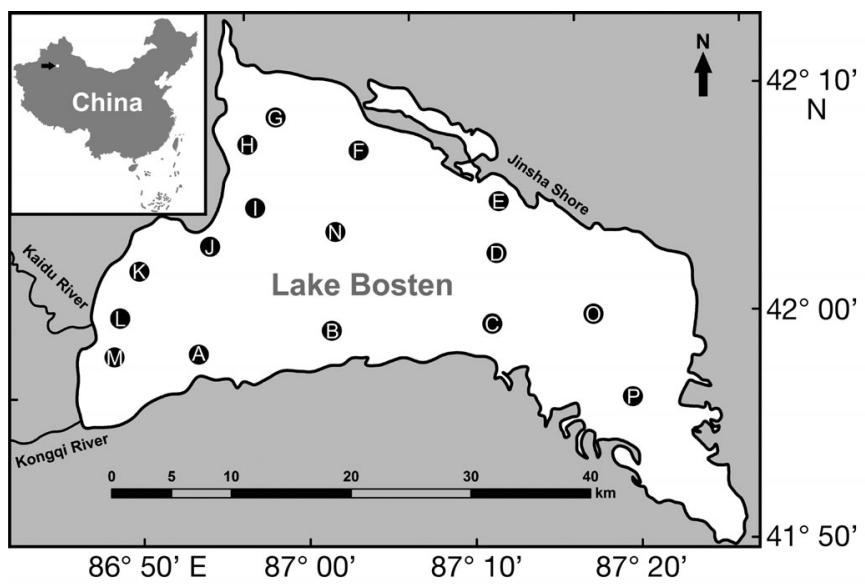

Fig. 1. Location of sampling sites in Lake Bosten, northwestern China 
tem (Thermo Scientific). The total organic carbon (TOC) in the sediment samples was determined using the standard $\mathrm{K}_{2} \mathrm{Cr}_{2} \mathrm{O}_{7}$ oxidation-reduction titration method, the total nitrogen (TN) was determined by the standard Kjeldahl method, and the total phosphorus (TP) was colorimetrically determined after $\mathrm{HClO}_{4}-\mathrm{H}_{2} \mathrm{SO}_{4}$ digestion, using the standard ascorbicacid method ( $\mathrm{Lu} \mathrm{1999).}$

\section{Bacterial cell counting}

The bacterial cell-counting protocol was modified from Martins's method (Martins et al. 2009). Aliquots of the stored sediment samples were first freezedried. Next, the freeze-dried sediment samples (1 g) were each fixed in $5 \mathrm{ml} 4 \%$ formaldehyde for $2 \mathrm{~h}$, centrifuged at $10000 \times g$ for $5 \mathrm{~min}$, washed with $5 \mathrm{ml}$ PBS buffer (10 mM NaH${ }_{2} \mathrm{PO}_{4}[\mathrm{pH} 7.2], 120 \mathrm{mM} \mathrm{NaCl}$ and $10 \mathrm{mM}$ sodium pyrophosphate) and centrifuged again as above. The reprocessed samples were stored in a mixture of $5 \mathrm{ml}$ PBS buffer and $5 \mathrm{ml} 100 \%$ ethanol at $-20^{\circ} \mathrm{C}$. To separate the bacteria from the sediment particles, aliquots of the reprocessed samples $(5 \mathrm{ml})$ were sonicated for $90 \mathrm{~s}$ at $30 \mathrm{~W}$ with a $5 \mathrm{~s}$ pulse mode and then allowed to rest for $5 \mathrm{~min}$ to precipitate the sediment particles. One microliter of the sonicated sample was then gradually diluted to 1:2500 with sterile water in sequential 10-fold dilutions. Aliquots of $5 \mathrm{ml}$ of the diluted samples were stained for $10 \mathrm{~min}$ in a glass filtering cylinder (Millipore) with 4',6-diamidino-2-phenylindole (final concentration of $5 \mathrm{mg} \mathrm{l}^{-1}$ ) (Porter \& Feig 1980, Gao et al. 2007). After $10 \mathrm{~min}$, the stained sample was filtered through a $0.2 \mu \mathrm{m}$ poresize polycarbonate filter (Millipore) and washed briefly with sterile water. The filtered membrane was mounted on a slide and observed with a Zeiss epifluorescent microscope (Carl Zeiss). For each filter, 20 fields were photographed randomly over the entire filter and counted manually. The final bacterial cell counts were calculated per gram of dry sediment.

\section{DNA extraction and denaturing gradient gel electrophoresis (DGGE) analysis}

DNA was extracted from $0.25 \mathrm{~g}$ freeze-dried sediment using a PowerSoil ${ }^{\circledR}$ DNA Isolation Kit (MO BIO Laboratories), as described by the manufacturer, and diluted to a final volume of $50 \mu \mathrm{l}$.

PCR amplification for DGGE was carried out using the $16 \mathrm{~S}$ rRNA gene specific primer $341 \mathrm{~F}$, with a $40 \mathrm{bp}$ GC-clamp attached to its 5' end, and the reverse primer 518R (Muyzer et al. 1993). PCR was conducted with $1 \times$ PCR buffer, $0.6 \mathrm{mM}$ dNTPs, $1.5 \mathrm{mM}$ $\mathrm{MgCl}_{2}, 0.1 \mu \mathrm{M}$ of each primer, $2.5 \mathrm{U}$ rTaq polymerase (TaKaRa) and sterilized water in a final volume of $50 \mu \mathrm{l}$. The PCR conditions were as follows: denaturation at $95^{\circ} \mathrm{C}$ for $5 \mathrm{~min} ; 35$ cycles of $45 \mathrm{~s}$ at $94^{\circ} \mathrm{C}, 45 \mathrm{~s}$ at $55^{\circ} \mathrm{C}$ and $1 \mathrm{~min}$ at $72^{\circ} \mathrm{C}$; a final extension step of 5 min at $72^{\circ} \mathrm{C}$. Triplicate PCR products for each sample were mixed and loaded onto an $8 \%$ polyacrylamide gel (acrylamide/bis-acrylamide: 37.5:1) in 1x TAE buffer (40 mM Tris, $20 \mathrm{mM}$ acetic acid and $1 \mathrm{mM}$ EDTA, pH 8.0) using a denaturing gradient ranging from $35 \%$ to $55 \%$ (100\% denaturant contained $7 \mathrm{M}$ urea and $40 \%$ deionized formamide). Electrophoresis was performed at $100 \mathrm{~V}$ and $60^{\circ} \mathrm{C}$ for $18 \mathrm{~h}$ with a DGGE-2001 system (C.B.S. Scientific). Next, the gel was stained with a 1:10 000 dilution of SYBR Green I solution (AMRESCO) for $30 \mathrm{~min}$ and then rinsed with Milli-Q water. The gel image was photographed with an Omega $10 \mathrm{Gel}$ image analysis system (UltraLum).

\section{S rRNA gene clone library construction}

Four bacterial 16S rRNA clone libraries were constructed for sediments taken from Sites D, G, L and N (Fig. 1). These sites were chosen based on the Shannon-Wiener index $\left(H^{\prime}\right)$ values of the DGGE-binary matrix data, which showed that the $H^{\prime}$ values were relatively higher at these selected sites in comparison to other sites in the same clustering group. 16S rRNA gene sequences were amplified from extracted environmental DNA samples using the eubacterial forward primer $27 \mathrm{~F}$ (5'-AGA GTT TGA TCM TGG CTC AG-3') and the universal reverse primer 1492R (5'GGT TAC CTT GTT ACG ACT T-3') (Newton et al. 2006). The PCR reaction mixture was the same as that in PCR for DGGE (see above). PCR was performed under the following conditions: denaturation at $95^{\circ} \mathrm{C}$ for $5 \mathrm{~min} ; 30$ cycles of $94^{\circ} \mathrm{C}$ for $45 \mathrm{~s}, 52^{\circ} \mathrm{C}$ for $90 \mathrm{~s}$ and $72^{\circ} \mathrm{C}$ for $1 \mathrm{~min}$; an additional $10 \mathrm{~min}$ of final extension at $72^{\circ} \mathrm{C}$.

Triplicate PCR products for each sample were mixed and loaded onto a $1 \%$ agarose gel. The target band was excised for each sample, and the gel fragments were purified with an AxyPrep ${ }^{\mathrm{TM}}$ Gel Extraction Kit (Axygen Biosciences) following the manufacturer's instructions. Purified PCR products were each cloned into $\mathrm{pMD}^{\circledR}{ }^{\circledR} 19 \mathrm{~T}$ vectors using the $\mathrm{pMD}{ }^{\circledR}$ $19 \mathrm{~T}$ Vector Kit (TaKaRa), according to the manufacturer's instructions. The plasmid containing the ligated PCR product was then transformed into Escherichia coli Top 10 supercompetent cells and 
incubated at $37^{\circ} \mathrm{C}$ by shaking at $150 \mathrm{rpm}$ for $1 \mathrm{~h}$ in an incubator. The incubated cells were then spread onto prepared solid Luria-Bertani (LB) medium plates and grown at $37^{\circ} \mathrm{C}$ for $16 \mathrm{~h}$. Randomly selected white colonies were incubated at $37^{\circ} \mathrm{C}$ for $8 \mathrm{~h}$ in liquid LB media to increase the yield of the plasmid DNA, respectively (Sambrook \& Russell 2001). The incubated liquid media samples were each then reamplified with the PCR program described above using the primers RV-M (5'-GAG CGG ATA ACA ATT TCA CAC AGG-3') and M13-47 (5'-CGC CAG GGT TTT CCC AGT CAC GAC-3') to verify the insert sizes and discard false positive clones.

\section{S rRNA gene sequence analysis}

Sequencing was conducted using an automated 3730 DNA capillary sequencer (Applied Biosystems). All partial 16S rRNA sequences were edited manually using the software BioEdit Sequence Alignment Editor (v.7.0.5.3) (Hall 1999) and examined for chimeric artifacts using the software Mallard (v.1.02) (Ashelford et al. 2006). The chimeric sequences were excluded from further analysis, and the remaining sequences were then blasted with the most similar 16S rRNA sequences from GenBank. The Ribosomal Database Project II (RDP II; http://rdp.cme.msu.edu/) classifier was used to assign taxonomic identities to our 16S rRNA sequences. When the sequence similarity was $\geq 95 \%$, which is the value corresponding to the separation of genera (Ludwig et al. 1998), the sequences were categorized as belonging to a member of the same genus as the most similar clone in the NCBI database. Sequences that had similarities to the closest clones or strains that were $<95 \%$ were labeled as 'unclassified'.

To examine the phylotypes of the available sequences in more detail, all of the available sequences in each clone library were first aligned using the software program Clustal X 1.83 (Thompson et al. 2002). Each alignment was then analyzed using the nucleic acid sequence distance matrix program (DNAdist, v.3.66) (Felsenstein 1993), and the output of this program was subsequently analyzed with DOTUR (Schloss \& Handelsman 2005) to compute the OTUs, Chao 1 richness estimator (Chao1), Shannon index $(H)$ and coverage index $(C)$. Coverage was calculated with the equation $C=\left[1-\left(n_{1} / \mathrm{N}\right)\right] \times 100$, in which $n_{1}$ is the number of single-occurrence phylotypes within a library, and $\mathrm{N}$ is the total number of clones in the library. Estimators were calculated using a genetic distance level of 0.03 .
Phylogenetic trees for sedimentary Alpha-, Beta-, Gamma- and Deltaproteobacteria were constructed using the Molecular Evolutionary Genetics Analysis (MEGA) software package (v.5.0) (Tamura et al. 2011). Node support was assessed by generating and summarizing 1000 bootstrap replicates, and evolutionary distances were computed using a JukesCantor model.

\section{Statistical analyses}

A principle components analysis (PCA) was conducted to identify differences in physicochemical parameters, while a redundancy analysis (RDA) (Ter Braak 1986) was used to examine the influence of environmental parameters on the sedimentary bacterial community structure. All the environmental parameters and the DGGE peak area data were $\log 10(x+1)$-transformed, with the exception of temperature and $\mathrm{pH}$. PCA of physicochemical parameters was conducted with SPSS 16.0 for Windows (IBM). RDA was conducted with the software CANOCO 4.5 (Ter Braak \& Šmilauer 2002). Environmental parameters were identified by forward selection using the Monte Carlo test, with 499 permutations under the reduced model. Clustering analysis of the DGGE-binary matrix data was performed using the GelCompar II software (Applied Maths), based on Dice distances. In addition, the 4 constructed clone libraries were compared statistically using the software J-LIBSHUFF (Schloss et al. 2004) to distinguish differences among them.

\section{Nucleotide sequence accession numbers}

All bacterial 16S rRNA gene sequences generated for the present study were deposited in GenBank under the accession numbers JN104732 to JN105080.

\section{RESULTS}

\section{Physicochemical parameters and bacterial cell abundances}

Spatial distribution of the investigated physicochemical parameters in the sediments and overlying water are shown in Fig. S1 in the Supplement at www.int-res.com/articles/suppl/a069p123_supp.pdf. There were significant environmental gradients from the freshwater region to the oligosaline re- 
gions, as revealed by the lower values of most physicochemical parameters at the freshwater sites in comparison with the oligosaline sites. We also found significant positive correlations among a number of the environmental parameters. For instance, sulfate was strongly correlated with chloride $(\mathrm{r}=0.817, \mathrm{n}=16, \mathrm{p}<0.001)$, as was TDS with salinity $(\mathrm{r}=0.999, \mathrm{n}=16, \mathrm{p}<0.001)$. From the PCA results, the first PCA component explained $58.6 \%$ of the total variance of the physicochemical parameters, while $71.4 \%$ of the total variance was explained by including the second PCA component. Salinity and TDS contributed more to the first component, while TP contributed more to the second component. The third component, which accounted for only $10.3 \%$ of the total variance, reflected the parameters of chloride and sulfate.

Bacterial abundances at different sites ranged from $1.53 \times 10^{10}$ to $3.77 \times 10^{10}$ cells per gram of dry sediment, with the abundances at the freshwater sites (Sites L and M) consistently lower than at the oligosaline sites (Fig. 2). The only significant correlation between bacterial abundances and physicochemical parameters was that between the overlying water DO concentration and bacterial abundance $(\mathrm{r}=$ $0.535, \mathrm{p}=0.033, \mathrm{n}=16$ ).

\section{Clustering analysis of DGGE profiles and RDA analysis}

The DGGE profiles of bacterial community structure in the sediments of Lake Bosten are shown in

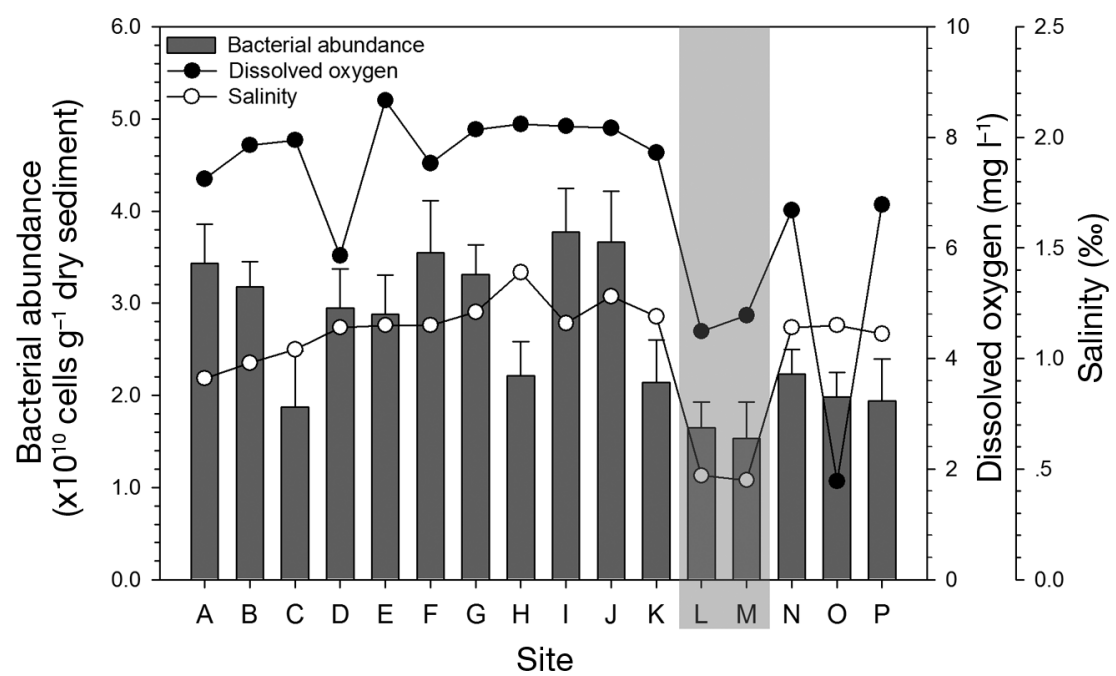

Fig. 2. Spatial distribution of sedimentary bacterial cell abundances, dissolved oxygen concentrations and salinity at the 16 sites investigated within Lake Bosten. The values for freshwater Sites L and M are shaded
Fig. 3. According to the marked bands in the gel image, the $H^{\prime}$ of bacterial communities varied from 2.76 at Site M to 3.55 at Site N. A clustering analysis of DGGE profiles based on Dice distances indicated significant heterogeneity in the sedimentary bacterial community structure. We recovered 4 major groups of sites using a similarity cutoff of $60 \%$. Groups 1, 2 and 3 belonged to the oligosaline regions, while Group 4 (Sites L and M) was localized to the freshwater region of the lake. Additionally, there was a significant Pearson correlation between the $H^{\prime}$ and salinity (Fig. 4).

Our RDA examined the significance of salinity, TP, $\mathrm{DO}$, sulfate and chloride in relation to the sedimentary bacterial community structure in Lake Bosten (Fig. 5). These 5 significantly correlated variables accounted for $56.0 \%$ of the sedimentary bacterial community variance in Lake Bosten. Salinity was the most important factor and accounted for $15.0 \%$ of the total variance in bacterial community structure $(\mathrm{p}=$ $0.006, F=2.40)$. Additionally, TP $(\mathrm{p}=0.018, F=2.24)$, DO $(\mathrm{p}=0.024, F=2.19)$, sulfate $(\mathrm{p}=0.028, F=2.14)$ and chloride ( $\mathrm{p}=0.038, F=1.92)$ accounted for 12.0 , $11.0,10.0$ and $8.0 \%$ of the sedimentary bacterial community variance, respectively.

\section{Diversity estimators of bacterial communities}

OTU identifications, Chao1, $H$ and coverage values for the clone libraries are summarized in Table S1 in the Supplement at www.int-res.com/ articles/suppl/a069p123_supp.pdf. A total of 185 OTUs were acquired from the 349 nonchimeric sequences with a similarity of $\geq 97 \%$. In the present study, the estimated coverage of each clone library was moderately high, ranging from 67.0 to $72.0 \%$. The highest diversity (Chao1 and $H$ ) was at Site D where the sedimentary TP content was the highest among all the investigated sites, whereas the lowest was measured at Site L in the freshwater region. J-LIBSHUFF was used to test the significant differences among the 4 clone libraries. The clone library at the freshwater Site L was significantly different from the other 3 clone libraries at oligosaline sites (see Table S2 in the Supplement). 


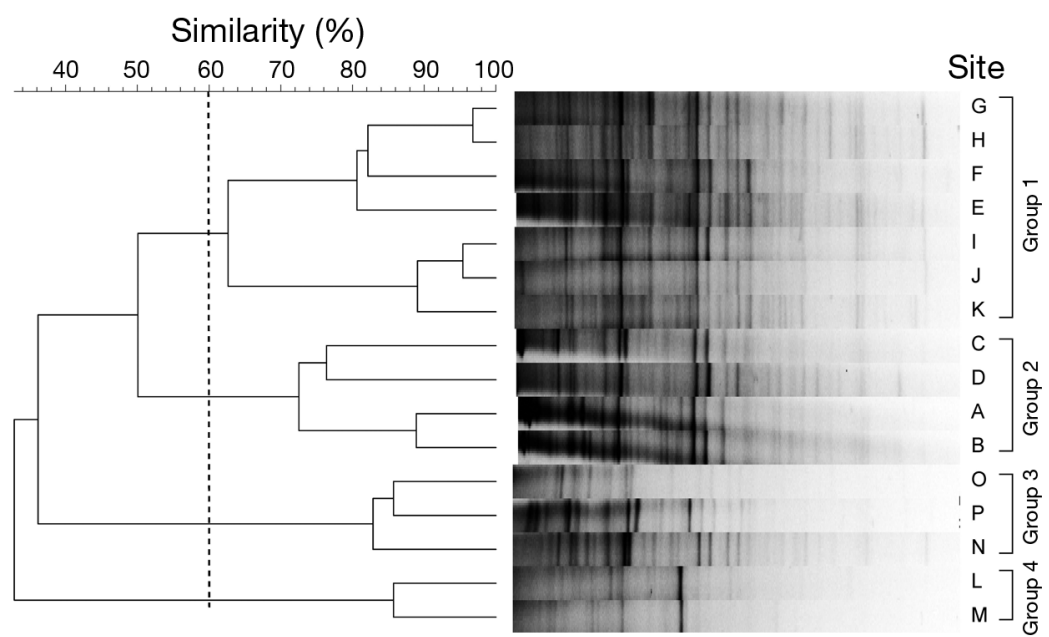

Fig. 3. UPGMA dendrogram of DGGE banding patterns based on the Dice similarity coefficient. The cutoff of the similarity level is indicated by the dashed line

\section{Taxonomic identification of 16S rRNA gene sequences}

The relative proportions of the taxonomic affiliations of 16S rRNA sequences at the phylum level within each library are shown in Fig. 6A. Proteobacteria was the dominant phylum at all 4 sites, with the relative proportions of $49.5,35.4$ and $55.1 \%$ in the samples from oligosaline Sites D, G and N, respectively, yet with the lowest relative proportion $(25.6 \%)$ at the freshwater Site L, in contrast to the other 3 oligosaline sites.

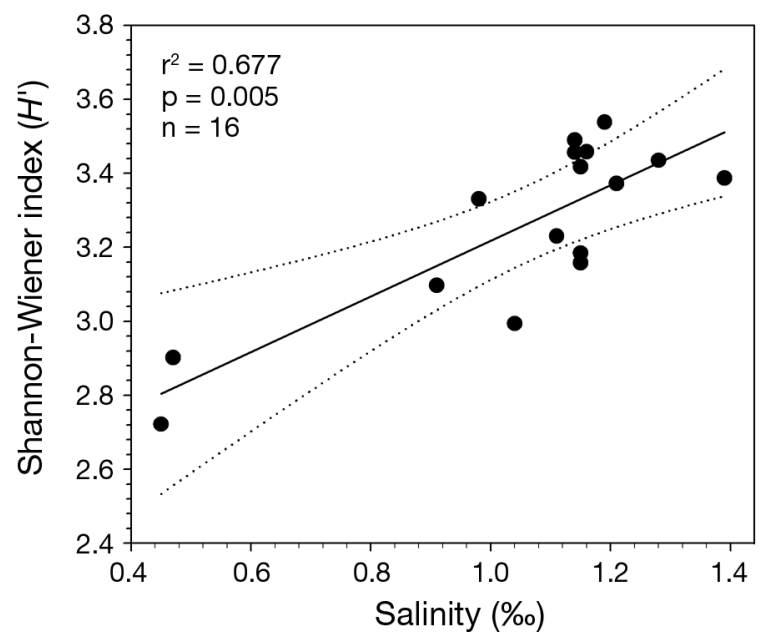

Fig. 4. Statistically significant linear regression between salinity and the Shannon-Wiener index $\left(H^{\prime}\right)$ of the DGGEbinary matrix data. The regression line is solid, and the dotted lines indicate the $95 \%$ confidence intervals
A total of 145 Proteobacteriaaffiliated sequences were acquired from the 4 clone libraries, which yielded 63 unique OTUs (including Alphaproteobacteria, 8 OTUs; Betaproteobacteria, 13 OTUs; Gammaproteobacteria, 17 OTUs; and Deltaproteobacteria, 25 OTUs) at the identity level of $\geq 97 \%$. The relative proportions of the 4 proteobacterial classes from each clone library are shown in Fig. 6B. Betaproteobacteria and Deltaproteobacteria were the dominant proteobacterial classes in the 4 clone libraries, with the relative proportions of Betaproteobacteria ranging from $24.4 \%$ at Site D to $42.9 \%$ at Site N and the deltaproteobacterial proportions ranging from $26.7 \%$ at Site D to $46.4 \%$ at Site G. In total, $36.6 \%$ of the proteobacterial sequences were affiliated with Deltaproteobacteria, and Betaproteobacteria accounted for $32.4 \%$ of the total proteobacterial sequences.

According to the phylogenetic analysis of Proteobacteria-affiliated sequences in Lake Bosten, some specific genera-affiliated sequences were identified, as indicated in Fig. S2 in the Supplement. Alphaproteobacteria harbored 7 specific genera clusters:

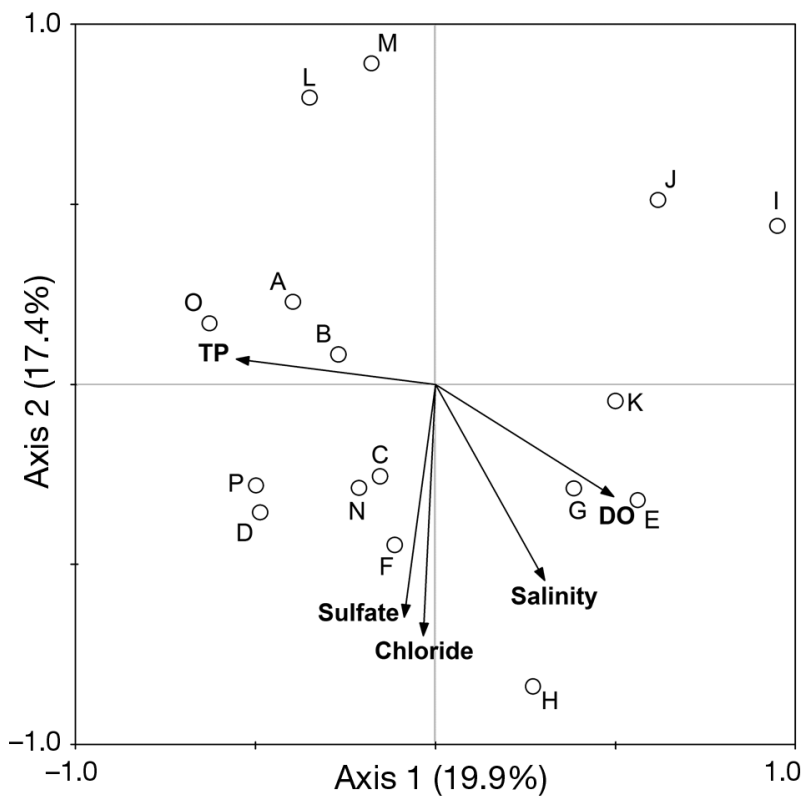

Fig. 5. Redundancy analysis (RDA) of sedimentary bacterial community structure in relation to the significantly correlated physicochemical parameters in sediments at Sites A to P of Lake Bosten. DO: dissolved oxygen; TP: total phosphorus; Sulfate: $\mathrm{SO}_{4}{ }^{2-}$; Chloride: $\mathrm{Cl}^{-}$ 
Fig. 6. Relative proportions of (A) the identified bacterial phyla and (B) proteobacterial classes recovered from the 4 16S rDNA gene clone libraries constructed from Sites D, G, L and $\mathrm{N}$ of Lake Bosten

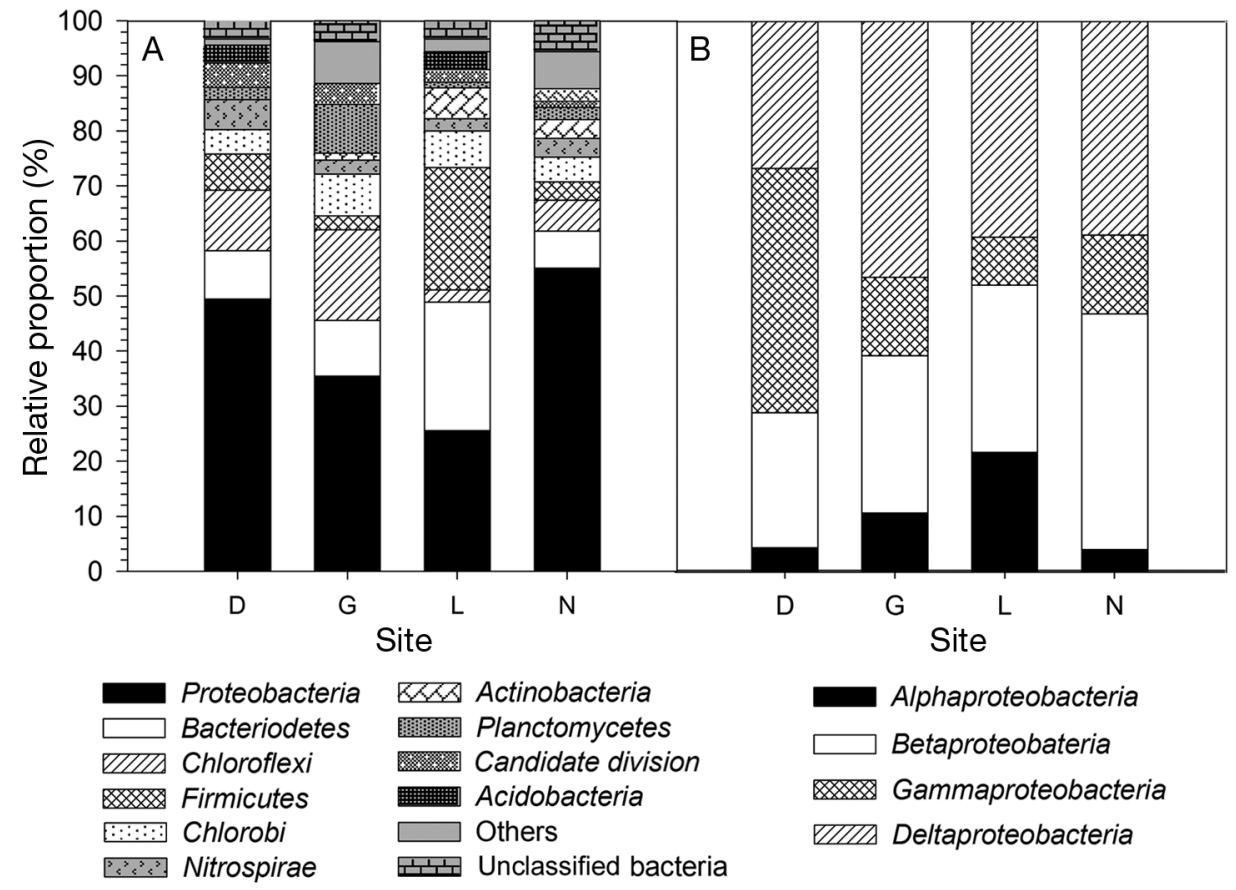

Six genera clusters were grouped into Deltaproteobacteria: Desulfobacter, Desulfobulbus, Geobacter, Desulfobacca, Myxobacter and Nannocystis (see Fig. S2D). Of these, the genus Desulfobacter was dominant and was found in each library (Fig. 7B). Four of these genera (Desulfobacter, Desulfobulbus, Geobacter and Desulfobacca) belonged to the putative sulfate-reducing bacteria (SRB). The sequences affiliated with these putative SRB accounted for $12.3 \%$ of the total bacteria surveyed and were the dominant members of Deltaproteobacteria, with percentages of $91.7,76.9,77.8$ and $88.2 \%$ for Sites D, G, $\mathrm{L}$ and $\mathrm{N}$, respectively.

In contrast with the 3 oligosaline sites, Bacteroidetes were most abundant at Site L $(23.3 \%$ of the total bacteria at Site L) (Fig. 6A). There were 5 genera clusters identified at the freshwater Site L: Flavobacter, Sphingobacter, Cytophaga, Niastella and Algoriphagus, while only Sphingobacter and Cytophaga were identified at the oligosaline sites (see Fig. S3A in the Supplement). In addition, $67.4 \%$ of the Bacteroidetes sequences belonged to the unclassified Sphingobacteriales.

Chloroflexi were found in each library, with the relative proportions ranging from $2.2 \%$ at Site $\mathrm{L}$ to $16.5 \%$ at Site G (Fig. 6A). Caldilinea was the only identified genus, and most of the Chloroflexi sequences were unidentified at the genus level, with the relative proportion of $>80.0 \%$ in each library (see Fig. S3B). Similar to the Bacteroidetes group, members of Firmicutes were also most abundant, with a Fig. S2C). 


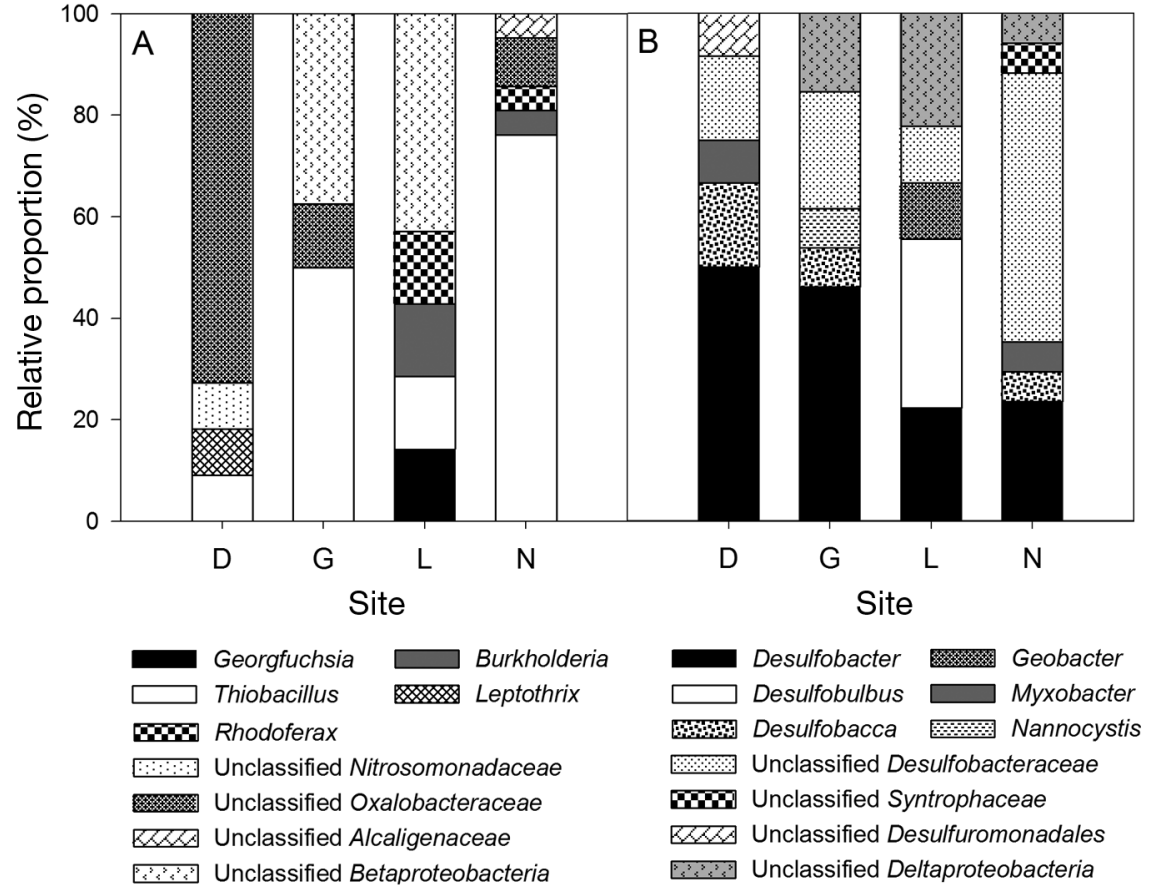

Fig. 7. Relative proportions of the identified genera and the unclassified groups of (A) Betaproteobacteria and (B) Deltaproteobacteria in the $416 \mathrm{~S}$ rDNA gene clone libraries constructed from Sites D, $\mathrm{G}, \mathrm{L}$ and $\mathrm{N}$ of Lake Bosten proportion of $22.2 \%$ of the total bacteria at Site L, when compared to the other 3 oligosaline sites (Fig. 6A). Five genera belonging to this group were identified in our study: Bacillus, Brochothrix, Carnobacter, Clostridium and Eubacter, of which Clostridium was the most abundant genus (see Fig. S3C). In addition, sequences affiliated with the phyla Chlorobi, Nitrospirae, Planctomycetes and Candidate division were also recovered in all 4 libraries (Fig. 6A).

\section{DISCUSSION}

\section{Effects of salinity and nutrients on sedimentary bacterial community structures}

During the past $20 \mathrm{yr}$, the hydrochemical condition of Lake Bosten has become the sodium sulfate type, and the salinity content (or TDS) has been mainly attributed to the sulfate and chloride sodium salts present in the lake (Li \& Yuan 2002). In the present study, sulfate and chloride were important parameters that influenced the heterogeneity of sedimentary bacterial communities in the lake (Fig. 5), and might be the direct factors influencing certain groups of sedimentary bacteria. This was also supported by the relatively high proportion of putative SRB in the sediments of Lake Bosten. However, salinity is an integrated variable that reflects the global level of aquatic dissolved solids concentrations (Lozupone \&
Knight 2007, Wang et al. 2011). Measurements of the water salinity in Lake Bosten have revealed that most regions of the lake are oligosaline (Xie et al. 2011). Although salinity levels in Lake Bosten are much lower than those in hypersaline lakes (Wu et al. 2006, Xie et al. 2011), salinity has become an obvious index of the gradual alteration of this ecosystem. PCA of the environmental parameters in our study demonstrated that salinity is the dominant factor shaping the microbial habitats of Lake Bosten.

The freshwater inflow of the Kaidu River shapes the freshwater region in the western district of Lake Bosten, which can be seen in the physicochemical properties of Sites L and M (see Fig. S1). Intriguingly, the sedimentary bacterial community structures at Sites L and M grouped together, separated from the other oligosaline sites (Fig. 3). In addition, the BCC at the freshwater Site L differed significantly from the other 3 oligosaline sites (see Table S2). Both the bacterial cell abundances (Fig. 2) and the DGGE based Shannon-Wiener index (Fig. 4) indicated that bacterial abundances and diversities increase along the salinity gradient from freshwater to oligosaline. In the present study, salinity was the most significant parameter influencing the bacterial community structures (Fig. 5). These results, combined with a significant positive correlation between salinity and the DGGE based Shannon-Wiener index (Fig. 4), demonstrate the effect of salinity on the sedimentary bacterial communities, which is consistent with pre- 
vious work conducted on bacterioplankton in Lake Bosten (Tang et al. 2012).

According to the sedimentary $\mathrm{TN}, \mathrm{TP}$ and TOC concentrations in our investigation and based on previous reports on water of this lake (Xie et al. 2011), it is clear that Lake Bosten is facing a new ecological crisis - namely, eutrophication. Agricultural wastewater, rich in nutrients, is contaminating the lake water. These nutrients are deposited in the surface sediment and contribute to the increase in nutrient levels throughout the entire lake. In the present study, TN, TP and TOC concentrations at freshwater sites were all lower than at oligosaline sites (see Fig. S1). Moreover, TP was the most significant factor shaping the sedimentary bacterial communities in Lake Bosten in the present study (Fig. 5). This is in addition to its known role in affecting the bacterioplankton distribution in the lake (Tang et al. 2012), which indicated the response of sedimentary bacterial communities to the nutrients gradient in Lake Bosten.

Moreover, DO was strongly correlated with bacterial community structures and cell abundances in our study (Figs. 2 \& 5). Oxygen is an important factor for regulating the metabolic activity of bacteria and is known to be an indispensible electron acceptor in many biochemical processes driven by bacteria (Nealson 1997). In Lake Bosten, the stream flow and allochthonous inputs of soil particles from the Kaidu River disturb the water of the freshwater region and decrease the oxygen concentration in the bottom water, which was an important reason for the lower bacterial abundances at the freshwater sites than at other oligosaline sites.

\section{Effects of salinity and nutrients on bacterial community composition}

Proteobacteria was the most abundant phylum, with Betaproteobacteria and Deltaproteobacteria predominating in all 4 libraries (Fig. 6). Betaproteobacteria are globally distributed in freshwater lakes, where they numerically dominate the cell biomass and bacterial types (Zwart et al. 2002, Tang et al. 2010). The presence and dominance of Betaproteobacteria may be related to their ability to quickly respond to changes in available nutrients, such as dissolved organic carbon (Newton et al. 2006). In Lake Bosten, the higher proportions of Betaproteobacteria at the 3 oligosaline sites compared to the freshwater Site L might be related to the more abundant sedimentary nutrients, including TOC, TN and
$\mathrm{TP}$, in oligosaline regions (see Fig. S1 in the Supplement). Moreover, Thiobacillus, mostly found in mine wastewater-contaminated habitats (Fortin et al. 1996, Robertson \& Kuenen 2006), was a dominant genus that was recovered at the oligosaline sites. This provides additional evidence for the sedimentary bacterial response to the enrichment of pollutants, including nutrients.

In the present study, most of the identified betaproteobacterial clusters were distinct from typical freshwater clusters previously characterized (Zwart et al. 2002), an observation that may be attributed to the oligosaline environment in Lake Bosten. However, the low abundance of Alphaproteobacteria, which are known to be competitive at low nutrient levels (Pinhassi \& Berman 2003), may be attributed to the high concentrations of nutrients in the sediments within Lake Bosten.

Gammaproteobacteria are generally more abundant in saltwater environments, such as oceans (Glöckner et al. 1999, Rusch et al. 2007, Biers et al. 2009) or saline lakes (Wu et al. 2006), than in freshwater environments (Wu et al. 2007, Mueller-Spitz et al. 2009). Indeed, the majority of the gammaproteobacterial clusters we identified have previously been sampled from saline environments. For instance, members of the genera Psychrobacter, Steroidobacter and Halomonas, which are often found in saltwater environments (Bowman et al. 1997), were recovered in oligosaline regions of Lake Bosten in our study. Moreover, the higher taxon richness of Gammaproteobacteria at the oligosaline sites than at the freshwater Site L supports the bacterial response to the salinity gradient in Lake Bosten.

Most of the Deltaproteobacteria we identified in Lake Bosten are affiliated with the putative SRB, which have been found to exist almost exclusively in various anoxic environments, such as estuarine and coastal marine sediments (Purdy et al. 2002), Antarctic marine sediments (Bowman \& McCuaig 2003), saline lake sediments (Koizumi et al. 2004) and freshwater wetland sediments (Ikenaga et al. 2010). Other studies have suggested that SRB are highly active and that they participate in anaerobic decomposition and the transformation of deposited organic matter in surface sediments (Soltwedel \& Vopel 2001, Bowman \& McCuaig 2003). The relatively high percentage of SRB might be due to the high concentrations of sedimentary sulfate and TOC, which can provide an ideal habitat for these functional bacteria.

Bacteroidetes were more abundant at the freshwater Site L than at any of the other 3 oligosaline sites. Site L is located near the mouth of the Kaidu 
River, and the freshwater inflow mixed with large amounts of particles flows into the western region of Lake Bosten, while the other 3 sites are in the eastern district with relatively low turbidity (water turbidity data not shown). Bacteroidetes is composed of a large proportion of particle-associated bacteria, which are especially common in freshwater lakes (Simon et al. 2002, Lemarchand et al. 2006, Tang et al. 2010). Because of the low hydrodynamic intensity in Lake Bosten, particles and associated Bacteroidetes were likely deposited on the surface sediment. Bacteroidetes are thought to play a critical role in freshwater environments by processing complex molecules into simpler compounds. Similarly, Firmicutes displayed a relatively high proportion at Site L, with Clostridium being the dominant genus. Clostridium is saprotrophic and is usually found in soils (Elshahed et al. 2008). Such a relatively high proportion of saprotrophic bacteria at Site L may be attributed to the soil particles carried by the inflow of the Kaidu River. Moreover, the lower relative proportion of Firmicutes at each of the 3 oligosaline sites is consistent with the findings of a previous study in the oligosaline Lake Namco, which is located on the Tibetan Plateau (Liu et al. 2010).

Numerous 16S rRNA sequences in the present study could not be identified at the genus level. For example, most of the Betaproteobacteria-, Deltaproteobacteria-, Bacteroidetes- and Chloroflexiaffiliated sequences were not classified to the known genera with a similarity level of $\geq 95 \%$. These unclassified bacterial phylotypes may reflect the unique bacterial communities in this oligosaline lake in the early stage of salinization and eutrophication and may even include unknown species unique to these transitioning environments.

Although there are several other bacterial phyla that may have participated in various biochemical processes in the sediments of Lake Bosten, the heterogeneous distribution of these dominant phyla between the freshwater and oligosaline regions revealed the response of the sedimentary BCC to increases in salinity and nutrient levels, which demonstrates that salinity and nutrients are the most important factors controlling sedimentary BCC in oligosaline lakes in the arid region of China.

\section{CONCLUSIONS}

The present work is the first report characterizing the sedimentary BCC in the oligosaline Lake Bosten. Our results demonstrate that salinity shapes the sed- imentary BCC in this oligosaline lake. Proteobacteria was the dominant phylum in Lake Bosten, with the classes Betaproteobacteria and Deltaproteobacteria being the most abundant. The responses of the sedimentary $\mathrm{BCC}$ to gradients in salinity and nutrient levels were reflected in both the higher bacterial diversities and higher percentages of Proteobacteria in oligosaline regions than in the freshwater region. The low percentage of typical freshwater bacteria, the presence of a relatively high proportion of SRB, and relatively high proportions of unclassified bacteria indicate the unique nature of sedimentary BCC in this oligosaline lake in the early stages of salinization and eutrophication. Our study has provided fundamental information about the sedimentary $\mathrm{BCC}$ of the oligosaline Lake Bosten, located in the arid region of China. This lake can now serve as a model for future studies examining environmental changes from freshwater/oligotrophic to oligosaline/ mesotrophic conditions. However, additional studies of limnic bacterial diversity and their function in aridregion lakes are still needed to better understand the influences of climatic drought and human activities on aquatic ecosystems.

Acknowledgements. This work was supported by the National Natural Science Foundation of China (grant 41171388), the Special Environmental Research Funds for Public Welfare of the State Environmental Protection Administration (grant 201309041) and the National Water Pollution Control and Management of Science and Technology Major Projects (grant 2009ZX07106-004). We thank the 3 anonymous reviewers and the editor for their thoughtful and constructive suggestions.

\section{LITERATURE CITED}

Ashelford KE, Chuzhanova NA, Fry JC, Jones AJ, Weightman AJ (2006) New screening software shows that most recent large 16S rRNA gene clone libraries contain chimeras. Appl Environ Microbiol 72:5734-5741

Bai J, Chen X, Li J, Yang L, Fang H (2011) Changes in the area of inland lakes in arid regions of central Asia during the past 30 years. Environ Monit Assess 178:247-256

Biers EJ, Sun S, Howard EC (2009) Prokaryotic genomes and diversity in surface ocean waters: interrogating the global ocean sampling metagenome. Appl Environ Microbiol 75:2221-2229

> Bowman JP, McCuaig RD (2003) Biodiversity, community structural shifts, and biogeography of prokaryotes within Antarctic continental shelf sediment. Appl Environ Microbiol 69:2463-2483

> Bowman JP, McCammon SA, Brown MV, Nichols DS, McMeekin TA (1997) Diversity and association of psychrophilic bacteria in Antarctic sea ice. Appl Environ Microbiol 63:3068-3078

Chen FH, Shi Q, Wang JM (1999) Environmental changes documented by sedimentation of Lake Yiema in arid 
China since the Late Glaciation. J Paleolimnol 22: 159-169

> Danovaro R, Manini E, Dell'Anno A (2002) Higher abundance of bacteria than of viruses in deep Mediterranean sediments. Appl Environ Microbiol 68:1468-1472

Dedysh SN, Knief C, Dunfield PF (2005) Methylocella species are facultatively methanotrophic. J Bacteriol 187: 4665-4670

Elshahed MS, Youssef NH, Spain AM, Sheik C and others (2008) Novelty and uniqueness patterns of rare members of the soil biosphere. Appl Environ Microbiol 74: 5422-5428

Felsenstein J (1993) PHYLIP: phylogenetic inference package, version 3.5c. University of Washington, Seattle, WA

Fortin D, Davis B, Beveridge T (1996) Role of Thiobacillus and sulfate-reducing bacteria in iron biocycling in oxic and acidic mine tailings. FEMS Microbiol Ecol 21:11-24

Fujii M, Kojima H, Iwata T, Urabe J, Fukui M (2012) Dissolved organic carbon as major environmental factor affecting bacterioplankton communities in mountain lakes of eastern Japan. Microb Ecol 63:496-508

> Gao G, Qin B, Sommaruga R, Psenner R (2007) The bacterioplankton of Lake Taihu, China: abundance, biomass, and production. Hydrobiologia 581:177-188

Glöckner FO, Fuchs BM, Amann R (1999) Bacterioplankton compositions of lakes and oceans: a first comparison based on fluorescence in situ hybridization. Appl Environ Microbiol 65:3721-3726

Hall TA (1999) BioEdit: a user-friendly biological sequence alignment editor and analysis program for Windows 95/98/NT. Nucleic Acids Symp Ser 41:95-98

> Ikenaga M, Guevara R, Dean AL, Pisani C, Boyer JN (2010) Changes in community structure of sediment bacteria along the Florida coastal Everglades marsh-mangroveseagrass salinity gradient. Microb Ecol 59:284-295

> Jiang H, Dong H, Yu B, Liu X, Li Y, Ji S, Zhang CL (2007) Microbial response to salinity change in Lake Chaka, a hypersaline lake on Tibetan plateau. Environ Microbiol 9:2603-2621

> Koizumi Y, Kojima H, Oguri K, Kitazato H, Fukui M (2004) Vertical and temporal shifts in microbial communities in the water column and sediment of saline meromictic Lake Kaiike (Japan), as determined by a $16 \mathrm{~S}$ rRNAbased analysis, and related to physicochemical gradients. Environ Microbiol 6:622-637

- Lemarchand C, Jardillier L, Carrias JF, Richardot M, Debroas D, Sime-Ngando T, Amblard C (2006) Community composition and activity of prokaryotes associated to detrital particles in two contrasting lake ecosystems. FEMS Microbiol Ecol 57:442-451

Li W, Yuan L (2002) On the water-salt change of Bosten Lake in Xinjiang. J Lake Sci 14:223-227 (in Chinese)

$>$ Liu X, Yao T, Kang S, Jiao N, Zeng Y, Liu Y (2010) Bacterial community of the largest oligosaline lake, Namco on the Tibetan Plateau. Geomicrobiol J 27:669-682

- Lozupone CA, Knight R (2007) Global patterns in bacterial diversity. Proc Natl Acad Sci USA 104:11436-11440

Lu R (1999) Analytical methods of soil agrochemistry. China Agricultural Science and Technology Press, Beijing

$>$ Ludwig W, Strunk O, Klugbauer S, Klugbauer N and others (1998) Bacterial phylogeny based on comparative sequence analysis (review). Electrophoresis 19:554-568

Martins JL, Silveira TS, Silva KT, Lins U (2009) Salinity dependence of the distribution of multicellular magneto- tactic prokaryotes in a hypersaline lagoon. Int Microbiol 12:193-201

Mischke S, Wünnemann B (2006) The Holocene salinity history of Bosten Lake (Xinjiang, China) inferred from ostracod species assemblages and shell chemistry: possible palaeoclimatic implications. Quat Int 154-155:100-112

> Mueller-Spitz SR, Goetz GW, McLellan SL (2009) Temporal and spatial variability in nearshore bacterioplankton communities of Lake Michigan. FEMS Microbiol Ecol 67 : 511-522

Muyzer G, de Waal EC, Uitterlinden AG (1993) Profiling of complex microbial populations by denaturing gradient gel electrophoresis analysis of polymerase chain reaction-amplified genes coding for 16S rRNA. Appl Environ Microbiol 59:695-700

Nealson KH (1997) Sediment bacteria: Who's there, what are they doing, and what's new? Annu Rev Earth Planet Sci 25:403-434

Newton RJ, Kent AD, Triplett EW, McMahon KD (2006) Microbial community dynamics in a humic lake: differential persistence of common freshwater phylotypes. Environ Microbiol 8:956-970

> Pinhassi J, Berman T (2003) Differential growth response of colony-forming alpha- and gamma-proteobacteria in dilution culture and nutrient addition experiments from Lake Kinneret (Israel), the eastern Mediterranean Sea, and the Gulf of Eilat. Appl Environ Microbiol 69:199-211

> Porter K, Feig YS (1980) The use of DAPI for identifying and counting aquatic microflora. Limnol Oceanogr 25: 943-948

Purdy KJ, Embley TM, Nedwell DB (2002) The distribution and activity of sulphate reducing bacteria in estuarine and coastal marine sediments. Ant Van Leeuwenhoek 81:181-187

Robertson LA, Kuenen JG (2006) The genus Thiobacillus. In: Dworkin M, Falkow S, Rosenberg E, Schleifer KH, Stackebrandt E (eds) Prokaryotes. Springer, New York, NY, p 812-827

Rusch DB, Halpern AL, Sutton G, Heidelberg KB and others (2007) The Sorcerer II global ocean sampling expedition: northwest Atlantic through eastern tropical Pacific. PLoS Biol 5:e77

Sai B, Huang J, Xie G, Feng L, Hu S, Tang X (2011) Response of planktonic bacterial abundance to eutrophication and salinization in Lake Bosten, Xinjiang. J Lake Sci 23:934-941 (in Chinese)

Sambrook J, Russell DW (2001) Molecular cloning: a laboratory manual. Cold Spring Harbor Press, New York, NY

Schloss PD, Handelsman J (2005) Introducing DOTUR, a computer program for defining operational taxonomic units and estimating species richness. Appl Environ Microbiol 71:1501-1506

Schloss PD, Larget BR, Handelsman J (2004) Integration of microbial ecology and statistics: a test to compare gene libraries. Appl Environ Microbiol 70:5485-5492

> Schmidt JL, Deming JW, Jumars PA, Keil RG (1998) Constancy of bacterial abundance in surficial marine sediments. Limnol Oceanogr 43:976-982

Simon M, Grossart HP, Schweitzer B, Ploug H (2002) Microbial ecology of organic aggregates in aquatic ecosystems. Aquat Microb Ecol 28:175-211

Soltwedel T, Vopel K (2001) Bacterial abundance and biomass in response to organism-generated habitat heterogeneity in deep-sea sediments. Mar Ecol Prog Ser 219: 291-298 
Tamura K, Peterson D, Peterson N, Stecher G, Nei M, Kumar S (2011) MEGA5: molecular evolutionary genetics analysis using maximum likelihood, evolutionary distance, and maximum parsimony methods. Mol Biol Evol 28: 2731-2739

Tang X, Gao G, Chao J, Wang X, Zhu G, Qin B (2010) Dynamics of organic-aggregate-associated bacterial communities and related environmental factors in Lake Taihu, a large eutrophic shallow lake in China. Limnol Oceanogr 55:469-480

Tang X, Xie G, Shao K, Sai B, Chen Y, Gao G (2012) Influence of salinity on the bacterial community composition in Lake Bosten, a large oligosaline lake in arid northwestern China. Appl Environ Microbiol 78: 4748-4751

Ter Braak CJF (1986) Canonical correspondence analysis: a new eigenvector technique for multivariate direct gradient analysis. Ecology 67:1167-1179

Ter Braak CJF, Šmilauer P (2002) CANOCO reference manual and CanoDraw for Windows user's guide: software for canonical community ordination (version 4.5). Microcomputer Power, Ithaca, NY

Thompson JD, Gibson T, Higgins DG (2002) Multiple sequence alignment using ClustalW and ClustalX. Curr Protoc Bioinformatics 2:1-22

Wang J, Yang D, Zhang Y, Shen J, van der Gast C, Hahn MW, Wu Q (2011) Do patterns of bacterial diversity along

Editorial responsibility: Rutger de Wit, Montpellier, France salinity gradients differ from those observed for macroorganisms? PLoS ONE 6:e27597

- Wu QL, Zwart G, Schauer M, Kamst-van Agterveld MP, Hahn MW (2006) Bacterioplankton community composition along a salinity gradient of sixteen high-mountain lakes located on the Tibetan Plateau, China. Appl Environ Microbiol 72:5478-5485

> Wu X, Xi W, Ye W, Yang H (2007) Bacterial community composition of a shallow hypertrophic freshwater lake in China, revealed by 16S rRNA gene sequences. FEMS Microbiol Ecol 61:85-96

> Xiao M, Wu F, Liao H, Li W, Lee X, Huang R (2010) Characteristics and distribution of low molecular weight organic acids in the sediment porewaters in Bosten Lake, China. J Environ Sci (China) 22:328-337

Xie G, Zhang J, Tang X, Cai Y, Gao G (2011) Spatiotemporal heterogeneity of water quality (2010-2011) and succession patterns in Lake Bosten during the past 50 years. J Lake Sci 23:837-846 (in Chinese)

> Zhang R, Thiyagarajan V, Qian PY (2008) Evaluation of terminal-restriction fragment length polymorphism analysis in contrasting marine environments. FEMS Microbiol Ecol 65:169-178

Zwart G, Crump BC, Kamst-van Agterveld MP, Hagen F, Han SK (2002) Typical freshwater bacteria: an analysis of available 16S rRNA gene sequences from plankton of lakes and rivers. Aquat Microb Ecol 28:141-155

Submitted: September 28, 2012; Accepted: March 13, 2013 Proofs received from author(s): May 7, 2013 